\title{
A Proactive Approach to Global Governance Is China's Historic Choice
}

\author{
He Yafei
}

\begin{abstract}
As the world moves from "governance by the West" to "co-governance by both the West and East," the inherent deficiency in current global governance architecture becomes obvious to all of us. The author, through his own experiences as both a practitioner and student of global governance, has highlighted where the deficiency is and how to remedy it. By explaining China's recent moves in proposing the Chinese dream and building "one belt and one road," the author suggests that China continue on this proactive approach in dealing with global governance and offers some ideas from Chinese cultural heritage on how to reform the global governance architecture, with an emphasis on the G20, as well as on what China and the United States can do together to achieve better global governance.
\end{abstract}

Keywords: Global governance; Chinese approach; win-win cooperation; Chinese Dream; international organization.

The year 2015 marks the seventieth anniversary of the founding of the United Nations. At this historical juncture, it is imperative to review the modern history of global governance and explore the right path to its reform.

National governance is a concept familiar to most people. The modernization of China's national governance capability and system is explicitly

He Yafei is Vice Minister of the Overseas Chinese Affairs Office of the State Council of the People's Republic of China.

(C) 2015 World Century Publishing Corporation and Shanghai Institutes for International Studies China Quarterly of International Strategic Studies, Vol. 1, No. 2, 183-204

DOI: $10.1142 /$ S2377740015500098 
mentioned as part of the comprehensive reform measures adopted by the Third Plenum of the 18th National Congress of the Communist Party of China (CPC). Good governance is needed at both national and global levels. Governance is certainly more complex and challenging globally for the simple reason that it is not even remotely possible to have a "world government."

As China has grown to be a global power riding waves of globalization in the last few decades, global governance has coalesced into an issue gaining attention from top leaders down to the man-on-the-street. It is mainly about what role China should play and what responsibilities it should assume as a global power, albeit a developing one.

\section{China's Role in Global Governance}

First of all, it is imperative to understand what is meant by global governance. It is a global system mainly composed of international organizations - both governmental and non-governmental, treaties and agreements - both bilateral and multilateral, universally accepted international laws, and norms of international practices. Nation-states accept and are part and parcel of this system.

The current system was built by American-led Western nations at the end of the Second World War. It has served the international community well for seven decades but it is evident that this system is increasingly inadequate in addressing challenges in the twenty-first century. With the shifting geopolitical landscape, global governance needs new direction and momentum for reform and readjustment to better suit the evolving global balance of power, both politically and economically. With China and other emerging powers gaining global influence, they involve themselves more deeply and substantially in global governance.

The Contest of the Century by Geoff A. Dyer about competition between China and the U.S. in the new century raises an interesting question: Will the twenty-first century continue to be an era of Pax Americana or one "coruled" by China and the U.S.? The author explains that China's economic model has been an astounding success while America's "Washington Consensus" has been a dismal failure, especially after the 2008 financial crisis. Should the U.S. fail to incorporate China fully into the global 
governance system, China may shape global governance in a totally different fashion from that of the West.

The current narrative of global governance has been dominated by pundits from the U.S. and other Western nations. To talk about philosophy, one refers to Greece. In global governance, it is all about America. The U.S. and other Western powers have defined the value system, rules, players, and objectives of global governance to cover every aspect of the international system. With the onslaught of the worst financial crisis, the West lost its grip on global governance, resulting in a change from "governance by the West" to "co-governance by the West and East," with a greater voice for developing nations. There are universal expectations for China to play a greater role befitting its growing power globally. It is China's historic choice and destiny to fulfill that role as China moves deeply into global governance, especially as it is going to assume the rotating Chair of the Group of Twenty (G20) in 2016.

"History is a mirror." In the history of global governance in modern times, China has morphed from "forced entrant into global governance" as a semi-colony to being a "passive player" and now a "leading player" as evidenced in recent practices of the G20. There were both painful and useful lessons in the last century, and the new horizon looms large for China to lead the reform of the global governance architecture in the twenty-first century.

As the second largest economy and a permanent member of the United Nations Security Council, China is definitely a global power to reckon with. As China moves to the center of the world stage, nobody doubts the central role China plays in global governance. Is the international community, China in particular, comfortable with this? The process of the G20 in recent years may serve as an example to illustrate pitfalls we have to avoid and opportunities to explore on our way forward to better global

\section{China is bound to}

play a constructive and leading role in global governance.

\section{governance.}

Ever since the 1990s, the world has witnessed the most fundamental transformations in global governance and international relations, demonstrated in everexpanding multi-polarization, economic globalization, cultural diversification, internet-led 
information-revolution as well as rapid industrialization and urbanization. Mankind has engaged in exploring ever so deeply and broadly such "new frontiers" as the outer space and cyberspace. These changes have brought about a totally different world and reconfiguration of balance of power as exemplified by the emerging powers represented by China, India, Brazil, Indonesia, South Africa, Turkey, and others. This "great convergence" as defined by historians has, in turn, fed the rapid advance of globalization all over the world.

Global governance has been so impacted head-on by these changes that its deficiencies are glaringly exposed, clearly showing that the current system is ill-suited to address global issues given the changing world political and economic realities. Developing countries in particular are calling for reforms in global governance. As a result, after the 2008 financial crisis, the Group of Seven (G7) had to give up the "driving seat" in global governance to the G20.

These challenges posed by geopolitical and civilization conflicts, financial and economic crises, food and water safety, energy security, environmental degradation, climate change, and global immigration have been put into sharp relief. Global summits have mushroomed trying to find global solutions to these problems, but without much success, except what was achieved by the G20 in arresting the global financial crisis during the first few years after 2008.

Ironically, we may have to credit the financial crisis for providing a "mirror" for us to see how much damage "greedy capital" could do to the world. The crisis broke out in the heart of the capitalist world and pushed the world's economy and finances to the brink of total collapse. The unfolding of the crisis took the lid off the gaping hole in global governance, revealing the impotence of Western powers as well as the global system (underpinned by neo-liberalism) to cope with such a crisis.

The most important and epoch-making decision by the G20 was made at the Pittsburgh Summit in Autumn 2009 to have the G20 replace G8+5 (G7+Russia and five developing nations of China, Brazil, India, South Africa, and Mexico) as the "primary platform for global economic governance" as expressed in the Summit Leaders Declaration.

Since the beginning of the twenty-first century, China has played an ever more important leadership role in global affairs, including global governance. Under the leadership of the Communist Party, the Chinese 
people have created a miracle in history by turning China from a povertystricken country with 1.3 billion people into the second largest economy of the world in the past three decades. China's rise is in lock-step with globalization by integrating into the global governance system while simultaneously influencing its evolution. On one hand, China firmly adheres to the path of socialism with Chinese characteristics. On the other, China has become part of the global chain of production, the center of global manufacturing, a major member of the world trade system, and thus a key part of global governance.

Many academics have summed up China's growth model as the "Beijing Consensus" and "China Model" versus the American "Washington Consensus." Though China has shied away from the terms of "Beijing Consensus" and "China Model," its success in adhering to socialism with its own characteristics, both in theory and practice, has challenged the existing global governance architecture, offering new options for other developing countries.

Another example of a global governance failure is evidenced in the loosening foundation and inadequacy of the International Nuclear Nonproliferation Regime. The tortuous route taken by the $6+1$ (Permanent Five plus Germany) in their negotiations with Iran on its nuclear program has had sobering effects, clearly showing that the existing non-proliferation regime is pretty fragile. Since coming into effect in the 1980s, the Nonproliferation Treaty (NPT) regime has been weakened rather than strengthened, with more countries "joining the nuclear club."

The fast pace of change is so dazzling that the world is becoming "a global village" with complex problems multiplying and crossing geographical boundaries, sectors, and space. No country can handle global governance issues single-handedly. We are witnessing financial and economic crises, terrorist attacks, energy security, and infectious diseases one after another. Even natural disasters seem to have become increasingly severe and frequent. All of these make people wonder what is happening to our world. How can we confront ever more complicated and severe global challenges? What major reforms must we undertake to improve global governance or should we simply replace it with something totally new?

Karl Marx's greatest contribution to the concept of global governance was his prescient prediction that globalization would follow the yearning for profit by monopoly capital and eventually lead to global economic 
crisis. The 2008 financial crisis that brought the world economy to its knees once again proved the vitality and relevance of his prediction. ${ }^{1}$

It is paradoxical that the current global governance system has to be maintained despite its flaws and while necessary reforms are being made, in the hope that it may become more pertinent to the changing geopolitical landscape. China is at a critical juncture in global governance and its future will shape the contours of the international environment for China's own continuous growth. There are four areas where China shall pay particular attention, in order to enhance global governance.

\section{Championing the Chinese Dream for More Democratic International Relations}

Safeguarding the global governance system while improving it through forward-looking reforms shall be China's priority in foreign policy as well as that of the international community. The Chinese Dream and China's efforts at democratization of international relations have contributed to a redesigning of global governance in a fundamental fashion.

Guided by President Xi Jinping's diplomatic strategy, China stresses the importance of ten principles promulgated at the Bandung Conference in 1955 in addressing global issues and dealing with international relations on the basis of justice, fairness, and a win-win approach through cooperation. These ideas are part and parcel of Chinese philosophy and culture or what is termed "Chinese Wisdom."

Take the "Chinese Dream" as an example. It is a concept raised by President $\mathrm{Xi}$ as he took The Chinese Dream and China's appeal for more democratic international relations are among China's biggest contributions to global governance. office representing the hundred-year aspiration of China and the Chinese people to rejuvenate the nation. What is equally important is the connectivity between the Chinese Dream and the dreams of other nations as emphasized by Chinese leaders repeatedly.

${ }^{1}$ Marx's Capital became so popular again after 2008 that it was out of print repeatedly. To understand global governance, this book by Marx is a must read. 
The Chinese Dream and its symbiosis with other national dreams have been accepted widely. The Chinese Dream is rooted in China's traditional philosophy and culture. It finds expression in China's diplomacy as peace, cooperation and development as well as democratization of international relations. The Chinese Dream and better global governance both aim to improve the security and living standards of people of China. Global governance on Western terms cannot function properly without reform should we wish to avoid the mistakes of the 2008 financial crisis.

Western global governance requires a uniformed architecture based on universal values defined by the West. This approach is definitely unrealistic as nations can only agree to the lowest common denominators. The long years in the UN-led negotiation on climate change is a case in point as it has dragged on for decades without much success.

At the 2009 United Nations Climate Change Conference in Copenhagen where I was involved in the negotiation, frustration was written on the faces of all delegations as they were unable to achieve even minimal consensus on an accord. Finally out of desperation, some 20-odd countries including China got together at the last moment to negotiate the accord throughout the night and were able to manage a compromise, only to be met with resistance the next day when the draft was put to the General Conference for adoption. The "Copenhagen Accord" was reached through such tortuous routes and was adopted only as an addendum to a brief resolution of the Conference that "note[d] the Accord." The upcoming Paris Conference at the end of 2015 will not be very different as shown by difficult negotiations so far.

It is clear to all that the key to success in global governance does not lie in building a universal value system. Rather, there is the need to find solutions based on global or regional consensus wherever possible to specific challenges facing the world through patient negotiations and consultations. The Chinese Dream and building a harmonious world may sound bland as compared to high-flying Western theories of global governance, but it is certainly more down to earth and tangible in seeking common understanding while recognizing differences, a traditional concept of "agreeing to disagree" in Chinese philosophy. The late Premier Zhou Enlai while attending the Bandung Conference in Indonesia in 1955 famously addressed on the cacophony of participating states: "China is here to seek unity and not to ask for quarrelling, to seek common ground and 
not to highlight differences." These words still echo in the conference hall at Bandung and elsewhere.

The Chinese Dream and China's call for democratization of international relations should be viewed as China's contribution to global governance reform.

President Xi Jinping put forward the concept of Chinese Dream to provide a tangible target for Chinese people to feel and hope for. It is compatible with the two "centennial goals" for China to be rich and powerful with people living happier lives. The rejuvenation of China is the essence of the Dream that dovetails with other national dreams of peace and prosperity and with better global governance. As far as international relations are concerned, the Chinese Dream is inseparable from peaceful development and democratization of international relations. China is determined to pursue such a path while expecting others to follow suit. President Xi further explains peaceful development as the concept of "win-win approach through cooperation" rooted in China's "five principles of peaceful coexistence" pronounced in the 1950s in contrast with the "zero-sum game" mentality.

The concept of "win-win approach through cooperation" does not advocate idealistic regional and global integration; instead, it seeks to build global governance architecture with nation-states as the cornerstone. When compared with the global governance architecture promoted by Western nations, the differences are obvious as outlined below:

China's approach to global governance offers a different, "softer" alternative from the Western one.

First, from a global viewpoint, the Chinese Dream stresses the symbiosis and connectivity between China's developmental strategy and those of other nations, as well as their mutual cultural enrichment. The interests of states and their people are aligned with one another. On the other hand, global governance defined by the West sets NGOs, businesses, and individuals against states, downgrading the role of states. Moreover, it creates a system where North and South or West and East as often understood in international relations are divided, with the North playing a dominant role. That is termed "governance by the West."

Second, the Chinese Dream favors democratization of international relations while safeguarding sovereignty and national independence. Western global governance tries to address issues essentially falling under nations' 
domestic affairs. The Trans-Pacific Partnership (TPP) still under negotiation is an example that it goes well beyond borders to address such issues as labor and environmental standards. For developing nations or small countries, it is more likely to mean "you do what I say," rather than an opportunity to jointly construct a system based on mutual benefit and respect for national sovereignty.

Third, in pursuit of the Chinese Dream, China hopes to find solutions to issues and even conflicts in international relations through dialogue and negotiation by political and peaceful means. "Do not impose on others what you yourself do not desire." This is the essence of Chinese wisdom or philosophy. On the other hand, Western global governance does not wish to be bound by peaceful means. "Humanitarian intervention," "human rights above sovereignty," and the "responsibility to protect (R2P)" are a few examples whereby global governance got mixed up within national boundaries with terrible consequences.

The final objective of the Chinese Dream and other national dreams requires us to address common challenges so as to create an international environment conducive to finding workable solutions. The most recent example is the idea of building a "new type of major-power relationship" characterized by "non-confrontation, non-conflict, mutual respect, and winwin through cooperation" between China and the U.S., an initiative proposed by President Xi Jinping and accepted by President Obama. On the other hand, global governance as enunciated by the West seeks governance architecture and corresponding institutions that manage global affairs mainly under the auspices of the U.S. and other Western powers. In the final analysis, what China proposes in the Chinese Dream and democratization of international relations is "defensive" in nature, as a strategy to ensure stability of national structure and relations among states, while "global governance" as such is "offensive" in essence, trying to maintain a dominant position for the West in the global governance system and institutions.

\section{Providing More Global Public Goods}

As a global power, China should undoubtedly provide global public goods in line with its historical responsibility and its status of a developing nation.

President $\mathrm{Xi}$ Jinping has promulgated the concept of "Great Power Diplomacy with Chinese Characteristics" that shall guide us in taking up a 
leadership position in global governance. China needs to take the opportunity offered by history to play a constructive and leadership role in global governance reform. Chinese national rejuvenation is close at hand now that its interest has been aligned with that of the world as a whole.

To understand what global governance means for China and what public goods China has provided and shall supply, we need to delve deeply into the history of global governance. It has a great deal to do with Chinese philosophy and wisdom that are so deeply embedded in Chinese cultural heritage.

For the original concept of global governance, one has to become familiar with the emergence and evolution of the concept of globalization. The framework concept of globalization was first proposed by the Trilateral Commission on American National Security headed by David Rockefeller and Zbigniew Brzezinski. This Commission is a close-knit club of international monopoly capitalists with the sole purpose of ensuring profits garnered by global capital through exploitation and management of global markets being kept in the hands of a few countries.

The most popular explanation of globalization probably comes from the book The World Is Flat by Thomas Friedman, a famous New York Times columnist. Mr. Friedman said quite insightfully that the core of globalization is the free movement of capital which will level the playing fields all over the world and allow the world economy to achieve equilibrium on its own. Though common understanding of globalization is free movement of productive factors, its key remains free movement of capital.

The new concept of global governance originated toward the end of the Cold War. In fact, it was formulated in the report by the Commission on Global Governance set up around the same time.

China was not unaware of its responsibilities even at that time. In 1974, the "chief architect" of China's Reform and Opening-up strategy, Mr. Deng Xiaoping, stood on the podium of the United Nations General Assembly appealing for the creation of a new international political, economic order that contained wellconsidered cultural and ideological thinking of China on global governance. The question is

China had been aware of its responsibilities in the world long before the concept of global governance was propagated at the end of the Cold War. whether the global governance system created 
within the framework of unequal, unjust, and unreasonable international order can really serve the interests of developing countries. Why is it so onerous to solve global issues? As is popularly understood, the fundamental problem that lies in that global order is not good enough or well developed. Advanced nations wish to have their monopoly capital running the world while developing nations want to establish an economic foundation for sustainable development in a stable global financial environment and under a sound economic order. The developed and developing nations have different agenda. What should we do about global governance and how can we readjust the existing world order to adapt to the changed reality?

It takes a long time to build a political, economic, and cultural world order that is fair, legitimate, and just, because the endeavor needs constant readjustment of interests and accommodation among nations in their pursuit of better global governance. The reverse is also true that better global governance will promote the formation and growth of a new world political and economic order. As an old saying goes, "one bite will not make you fat." Historical processes such as those mentioned above cannot be rushed.

The Chinese civilization has contributed to the concept and ideas of global governance since its inception. First and foremost is the concept of peace. The book Lao Tzu said,

All things leave behind them the Obscurity (out of which they have come), and go forward to embrace the Brightness (into which they have emerged), while they are harmonized by the Breath of Vacancy.

Confucius said in his Analects, "The gentleman aims at harmony but not at uniformity. The mean man aims at uniformity but not at harmony." The two ancient Chinese scholars thus explained the interdependent relationships among everything under the sun and between men. The idea of harmony between man and nature in the Chinese civilization is highly applicable in today's endeavor to tackle global governance issues like climate change.

Inclusiveness and openness is another contribution to human progress from the Chinese civilization and it becomes an inalienable part of the global governance concept. The Book of Historical Records (Shangshu) contains 
the idea that "inclusiveness is great." It is also said in Lao Tzu that "[Whoever accepts nature's flow becomes all-cherishing;] Being all-cherishing he becomes impartial; Being impartial he becomes magnanimous; being magnanimous he becomes natural; being natural he becomes one with the Way; being one with the Way he becomes immortal: Though his body will decay, the Way will not." In short, that "all rivers run into the sea" expresses the character of the Chinese civilization.

From the perspective of inclusiveness, examples abound in the Chinese history from the Warring States Period when Confucianism, Mohism, Taoism, Legalism, Naturalism, and other schools of thought co-existed and freely competed with one another, to the Yuan Dynasty established by the Mongols that opened up sea routes from south to north, and on to the Qing Dynasty established by the Manchurians when China peaked in its wealth and regional influence in history.

From the perspective of openness, the core idea of governance is always human and people first. "Water carries boats but also capsizes them." "Listen to both sides and you will be enlightened; heed only one side and you will be benighted." These examples are self-explanatory.

Innovation and openness are an important historical lesson in the Chinese civilization As core values of the Chinese civilization, inclusiveness and openness are crucial to today's global governance. and the key to its uninterrupted history. This is of empowering significance to reforming global governance to adapt to today's changing world.

The ability of self-renewability in the Chinese civilization comes from the concept of "change." The famous Book of Changes asserts that daily renewal is essential to greatness and life after life derives from changes. The most fundamental idea in Chinese philosophy is that the universe is like a great river that constantly changes. Chinese civilization has lasted over several thousand years during which reform has been a constant, bringing about civilization progress each time, such as replacing fiefdom with an administrative system based on "counties" and replacing selection of officials only through recommendation by that of uniformed examinations.

Openness created the great Han and Tang dynasties where the Chinese civilization reached unprecedented levels. During the Han Dynasty, 
communication routes were opened to the West through Central and West Asia which enriched the Chinese civilization. Buddhism came to China in 2 A.D. and had great and lasting impact on Chinese culture from thinking and lifestyles to arts and literature. During the Tang Dynasty the Silk Road was opened up, leading to increasing cultural exchanges between China and the rest of the world. Those cultural exchanges promoted a close relationship between China and other countries, involving China deeply in the process of globalization and, by extension, in global governance.

It is obvious that economic globalization and global governance is not new to China. For China, globalization has promoted economic exchanges among nations and contributed to the reduction of differences among them through cultural integration and plurality of human civilization. With regard to global governance, balance must be found between national and global culture because a national culture in isolation is extremely difficult to maintain while a uniformed global culture is also impossible to achieve.

The Communist Party of China believes in communism and its final triumph. Since 1921 when the CPC was founded, it has fought generation after generation for its ideals. Through decades of efforts to achieve its ideals in combining Marxism with Chinese characteristics, the CPC has begun to appreciate that China is still at the preliminary stage of socialism and that it will take generations to complete socialism. By the same token, it will be some time before the international community can build up a more just, legitimate, and fairer global governance system.

\section{Encouraging Win-Win Results through Cooperation}

Over the past years, China has been more firmly committed to building a network of global partnerships by a win-win approach while trying to construct a new type of major power relations with the United States.

A most recent example in this regard is the concept of building a "Silk Road Economic Belt" and a "Maritime Silk Road" (termed the "one-belt and one-road initiatives" in short) aimed at regional integration and coprosperity, which is promulgated as China's answer to the key challenge of fragmentation in global governance to address the inherent deficiency of the global governance architecture. 
The inherent deficiency in global governance came into view early, but the urgency to reform global governance did not gather much momentum until the 2008 global financial crisis. The crisis wiped out trillions of dollars in global wealth in one sweep, revealing glaring failures of the global governance system and its institutions. It was also an eye opener to the inherent deficiency of the U.S. dollar-centered international monetary system.

When Lehman Brothers collapsed on September 15, 2008, it triggered the double bubble bursts of the American real estate and financial derivatives markets, leading to an almost total global financial meltdown. The dark clouds of economic recession shadowed over the U.S. first, quickly engulfed EU countries and then hit emerging markets with shock waves still being felt in many nations.

The rise of the Tea Party within the Republican Party in the U.S. and the result of the EU Parliament election in 2014 clearly show that such populist parties as the French National Front, the Dutch Freedom Party, the United Kingdom Independent Party (UKIP), and the American Tea Party are in the ascendant. Global governance has kissed good-bye to economic stability and entered an era of further fragmentation and reform.

The 2008 financial crisis was a watershed event for global governance, signaling the total defeat of the "Washington Consensus" and unmistakable failure of the Western-dominated global governance system. Heated debates are raging everywhere about what to do next and the development models that would be better suited to changing realities on the ground. The passions surrounding these debates are not just about which development model is better, such as China's or America's. They are about the crucial question that people all over the world are asking: what should be the direction for future global governance? It is safe to say that this is not only about global governance but more about different ideologies undergirding global governance architecture.

Renowned Chinese economist Lin Yifu, once Chief Economist of the World Bank, says that many Western economists insist on a democratic political system being essential to sustainable economic development. Their assertion has been smashed to pieces by facts which show that countries like the Philippines, Pakistan, India, and Bangladesh plus quite a few African nations that inherited either American or British political systems after decolonization have all fallen without exception into the 
"middle income or low income traps." American political scientist Francis Fukuyama in his essay "What is Governance" also pointed out that constitutional democracy is neither the necessary condition nor a sound basis for "good governance."

Since reform and opening up in the late 1970s, China has tenaciously taken the path of socialism with Chinese characteristics and, through repeated practices, has built up its own model of development and corresponding institutions amid continuous mudslinging by the West. By following its own development model, China has managed to achieve astonishing economic progress unheard of in human history that is attractive to many developing nations. China receives dozens of heads of state or government each year from Asia, Africa, and Latin America. China has established high-level dialogue forums and summit mechanisms with them. Officials from developing nations say that what is more important to them is not China's financial assistance, but developmental experiences China shares with them. China for that matter always believes that it is more important to help others "how to fish" in order to help aid recipient countries build up their foundation for sustainable economic growth.

That does not mean that China offers more words than action. Latest statistics show that from 2010 to 2012, China's foreign aid amounted to 89.34 billion RMB/Yuan, and the accumulated amount of aid since the founding of the PRC in 1949 has totaled 345.63 billion RMB/Yuan.

As the UN reviews the past 15 years of Millennium Development Goals (MDGs) and ponders Sustainable Development Goals (SDGs) for the next 15 years, China has a great deal to offer in regard to its development experiences. Take poverty reduction for example. China takes the lead in success of reducing poverty - the last three decades witnessed more than 600 million people in China being lifted out of poverty according to the World Bank criteria of under 1.25 dollar per day, taking up over 70 percent of the world total. China's success in poverty reduction provides roadmaps for other developing nations engaged in the same endeavor.

China has integrated economic development in its foreign assistance as China's contribution to global governance. The Ministry of Commerce trains over 20,000 officials from developing nations annually, mainly on national economic development strategy; poverty reduction strategy; rural development strategy, etc. At the same time, China cautions that its model of economic development should not be blindly copied as each country 
should formulate its own development and poverty reduction strategy based on its own national conditions.

China holds dear in its diplomacy and global governance the idea of win-win results through cooperation, believing in what Mencius said: "In dire straits the pioneers could only develop their own goodness. Successful, they could share their goodness with the whole world." China hopes that the dividends of its economic growth will benefit other countries to expand South-South cooperation and promote SouthNorth collaboration as proposed by President $\mathrm{Xi}$ at Bandung in April 2015.

In 2014, President Xi Jinping stressed in his speech to the Mongolian Parliament that China welcomed others to free-ride on China's "express train" of development. In its cooperation with other countries, China will not engage in "I win and you lose" or "I win more and you win less" type of cooperation. China's win-win approach stands in sharp contrast to complaints by U.S. officials of China "free riding" on the global governance system.

China's win-win approach and concrete contribution stand in sharp contrast to the assumption that it is a "free-rider" of the global governance system.

China's foreign aid has never had any political strings attached because China upholds the principle of non-interference in others' internal affairs, fully respects diversification of civilizations and development models, and respects the right of recipient countries to freely choose their own model and path of development. These ideas come from the Chinese cultural tradition of "An exemplary person (junzi) aims at harmony but not at uniformity. Roads can be parallel but do not have to be identical" and "things can grow together but do not have to harm one another." Another anchor for China's idea of diversity is deeply rooted in the five principles of peaceful coexistence as pronounced in the 1950s that formed the foundation for the 10 principles of the Bandung Conference in dealing with inter-state relations.

In the last few decades, China, alongside many other developing nations, has followed the economic model of manufacturing goods with large amounts of inputs of labor and resources for consumption in the West 
at the expense of the environment. The foreign exchanges thus earned are perpetually recycled back to the U.S. in the form of U.S. Treasury bonds. This global governance system cultivates an international economic and financial cycle with the U.S. dollar at the core, a typical example of "the rich feeding on the poor."

It is well known that global imbalance appeared right after humans created metal money with credit and debt. The present global imbalance is between countries with trade surplus and deficits with the U.S./West and China/East Asia as major players. From the perspective of global interdependence, China and the U.S. are really "twins." The global imbalance at current level is mainly a result of the inherent deficiency of the U.S. Dollar-centered world monetary system. Because of the dollar's major reserve currency status, the U.S. is in principle the only country where the Federal Reserve is able to print money at will and American consumers are able to spend at will because other countries like China with reserves in dollar-denominated assets will foot the bill in the end. Since the financial crisis, the Fed has engaged in several rounds of "quantitative easing (QE)," the source of global financial bubble and trouble. Conditions are not yet present for the Special Drawing Rights (SDR) of the IMF or any supranational currency to replace the U.S. Dollar as the international reserve currency. What should be done now is to limit the supranational power of the U.S. to use the dollar's "exorbitant privileges" whenever it sees fit. Measures should be taken through the IMF, G20 and other institutions or institutional arrangements to make it possible for countries with large foreign exchange reserves to reduce their dollar assets.

\section{Enhancing Reform of the Global Governance System}

Better global governance entails building a better governance architecture by reforming institutions like the IMF and the World Bank while making better use of the G20 and other upcoming mechanisms to help developing nations gain a louder voice in global governance.

The IMF and the World Bank are important parts of the Bretton Woods structure whose mandate is to ensure stability of the global economic and financial system so as to avoid repetition of what had happened during the 
1930s. In reality, however, from the 1970s onwards, the IMF and the World Bank have adhered to the market fundamentalism of the West in their ideology.

The IMF is mandated to maintain stability of interest rates and the global monetary system. Yet any major decision must have 85 percent of weighted votes and the U.S. has 16.75 percent. It is crystal-clear that the U.S. has nearly total control of the organization. Each year the IMF engages member states in economic and monetary policy dialogues. Representatives of the IMF are treated as emissaries of God. Trepidation and fear is the hallmark for governments of small countries who are hard pressed to heed and accept "guidance" from the IMF. With its structural deficiency, the IMF is powerless in dealing with the U.S. and Europe and as well as their exchange rates policies. On the other hand, the IMF has become an instrument on behalf of the West to promote the "Washington Consensus" in developing countries. Any country that needs assistance from the IMF has to accept economic and monetary policy "prescriptions" of total privatization and market freedom no matter what effects they would induce.

The World Bank is mandated to provide aid to developing countries for infrastructure and reduction of poverty. It has done more in terms of the latter than the former. It also became part of the unbalanced infrastructure in the promotion of neo-liberalism with its aid allocated on the basis of recipients meeting the criteria set by the West. Nevertheless, the World Bank has indeed done a great deal in helping developing nations in their economic growth. China itself has benefited from the World Bank's aid and development experiences.

As far as the WTO is concerned, its predecessor GATT successfully concluded the Uruguay Round in 1994 that started in 1986 and reduced tariffs in international trade, with tariffs on industrial goods from developed countries dropping from 40 percent to 4.7 percent and that from developing countries to below 13 percent. But the Doha Round has been confronted with a different fate ever since it began in 2001. Advanced nations have been dragging their collective feet. Urged on by the new Director-General from Brazil it managed to achieve something at the end of 2013 in Bali, Indonesia. Even then, such mediocre progress was stalled in mid-2014 by India on agriculture subsidy. In fact, developed nations seem to have given up on engaging in the WTO mainly because developing nations have grown stronger within it. The U.S. and other developed 
nations have turned their attention to trans-regional FTAs that they can better control such as TPP and TTIP.

\section{Effective global}

governance entails

new consensuses,

new mechanisms and

new frameworks

of cooperation.

As we enter the twenty-first century, global governance needs new consensuses, new mechanisms, and new frameworks of cooperation. Under the shadow of slow economic recovery, countries developed or not are all trying their utmost in seeking economic transformation and new growth points so as to achieve global rebalance. There are some key global governance issues that need to be addressed now, including the widening gap between the rich and poor, both within and among nations, and reform of the global financial regulatory system.

It is worth noting that with growing economic power, major developing nations (especially BRICS) are fast becoming primary movers in reforming global governance. They want the system to be stable because they have benefited from it, but at the same time they feel the urgency in reforming the system as they have from time to time been victimized by the unfairness and injustice inherent in the system.

The U.S. and other Western nations also want to change the system but for a different purpose. They believe that China and other major developing nations are "free riders" in the global governance system. This does not hold water. China started to open up and reform in the late 1970s and joined the WTO in 2001. During the whole time, China has integrated itself into the global governance system, including the global trading and investment system. China not only produces huge numbers of consumer goods but also "recycles" a large part of its foreign exchange earnings back to the United States to purchase U.S. Treasury bonds. Unfortunately, many Western commentators simply turn a blind eye to these contributions while criticizing China as a "free rider."

Global governance by the West has in recent years deviated from the beaten path toward "co-governance by both the West and the East" which motivates the U.S. and other Western nations to change the "rules of the game." It is exactly for that reason that the U.S. is pressing ahead with negotiations of the TPP and TTIP as well as the Service Trade Agreement with 20-odd members. Unfortunately, all the three "big 
negotiations" exclude China. It can be seen that China and other developing nations are not exempt from the duality of conservatism and progress revealing the complexity, multiplicity, and procrastination in global governance reform.

In terms of economic policy, many developing countries with painful lessons from their past adoption of neo-liberalism have abandoned the "Washington Consensus." Brazilian economist Dos Santos once branded Reagonomics as "disaster political economy," believing that Latin American countries had fallen into the "neo-liberalist trap." The critique of neo-liberalism is not limited to developing nations. It also has the support of leaders from advanced nations. Former British Prime Minister Gordon Brown expressly pronounced the death of the "Washington Consensus" at his press conference of the G20 London Summit in 2009. Such conflicting views have led to further fragmentation of the global governance system.

Developing countries now choose to have economic policies that are better suited to their own conditions by focusing on comprehensive development with the belief that infrastructure building and investments in industry and manufacturing are essential to their sustainable economic development. In global and regional governance, developing nations wish to break down the unjust and unfair economic order and achieve trade and investment liberalization through "interdependence with win-win and mutually beneficial approach." This is also why developing nations wish to learn from China's success in economic development and find their own growth models.

\section{Looking Ahead...}

The BRICS countries, urged by China, have taken the lead in providing a top-down design for reforming global and regional governance. On March 20, 2012, leaders from BRICS countries issued the "New Delhi Declaration" calling for the establishment of a new global financial system. One year later, the BRICS summit in South Africa laid out a "roadmap" for setting up its own development bank. In July 2014, BRICS leaders announced in Brazil the official establishment of its Development Bank with an initial paid-in fund of 50 billion dollars and with its headquarters in Shanghai. Meanwhile, the Emergency Reserve Arrangement was also set up with 100 billion 
dollars. China embraces its responsibility bravely and by its own actions has broadened cooperation in international finance, thus contributing its share in redesigning financial global governance. The establishment of the Bank and the Fund by BRICS countries is not meant to replace but to supplement the IMF and World Bank.

China has become the second largest economy and largest trading country in goods, with a foreign exchange reserve around 4 trillion dollars, but these achievements have not been translated into a greater voice in the international financial and monetary system. Recent years have witnessed greater uses of the RMB (Yuan) as a global currency of trade settlement and rapid pace of its internationalization, but not much has changed as far as the dollar-centered global financial system is concerned. Fluctuations in prices of bulk commodities and other financial risks have increased rather than decreased. Other developing nations face similar challenges and are thinking hard on ways in which global and regional financial governance systems may be reformed for the better.

Proceeding from the interests of Asia and other developing nations, China has taken the lead and proposed building new "silk roads" both on land westward and on the sea southward, including setting up the Asian Infrastructure Investment Bank (AIIB), now with 57 initial members from all over the world. This proposal of China proceeds from the spirit of "winwin results through cooperation" at the core of President Xi's big power diplomatic thinking which is China's guide in dealing with both regional and global governance.

On one hand, there is a wide gap between what Asian countries need in infrastructure finance and how much capital is available from the World Bank and the Asian Development Bank. The gap could be as big as 730 billion dollars each year with 11 trillion dollars for the next 15 years. On the other hand, many Asian nations have come to the conclusion that it is not advisable for Asia (East Asia in particular), - the world's fastest growing region - to be hijacked in its finance by the U.S. Dollar-centered system. Asian nations have accumulated huge amounts of foreign reserves simply to serve as cushions or "wave-breakers" against possible financial upheavals.

The establishment of the BRICS Emergency Reserve Arrangement is a self-rescue measure warranted from painful experiences of developing 
nations both in the Asian and global financial crises. Asian countries remember vividly even today, that during the Asian financial crisis in the late 1990s, Thailand and other Asian nations were forced to seek emergency aid from the IMF with suicidal package deals. The BRICS Emergency Fund belongs to the developing world and will provide assistance to developing nations. The Fund with 100 billion dollars is expected to increase in scope later on, which will greatly increase the authority and attractiveness of the BRICS countries and currencies. All the above-mentioned financial arrangements are solid contributions by China and developing nations to global governance reform.

To the vast developing world, lasting economic growth serves as a necessary foundation of progress in the political, social, cultural and other fields. The G20 has been moving forward in a zigzag fashion after the first few years of success in combating the financial crisis. As the imminent danger of the global financial meltdown fades, the spirit of "being in the same boat" dissipates too. As China becomes part of the triage in the G20 leadership and is poised to host the G20 summit in 2016, it shall again take the lead to offer its ideas and suggestions for the reform of global governance architecture. China, as a major global power and a permanent member of the United Nations Security Council, shall play a more active role in seeking solutions to global security issues too, including the fractured nuclear non-proliferation framework, to beef up the Security Councilled collective security system. The world can rest assured that China will by no means shirk its responsibilities. 